\title{
Demographic and Psychographic Characteristics of Patients with Molar Impaction 3 on the Approval of Surgery in Dental and Oral Polyclinic
}

\author{
Nasri $^{1}$, Sri Subekti ${ }^{2}$, Bedjo Santoso ${ }^{3}$, Ratna Wilis ${ }^{4}$ \\ ${ }^{1,4}$ Poltekkes Kemenkes Aceh, \\ ${ }^{2}$ RSUP Dr. Kariadi Semarang, \\ ${ }^{3}$ Post Graduate Program, Politeknik Kesehatan, Kemenkes Semarang \\ *Corresponding Author: Bedjo Santoso, Politeknik Kesehatan, Kemenkes Semarang, Jl. Tirto Agung \\ Pedalangan, Banyumanik, Indonesia, Email: bedjosantoso27@gmail.com
}

\begin{abstract}
:
Background: One of the factors that become an obstacle to operation in preoperative problems is fear. Also, patient characteristics factors such as age, education, and occupation also play a role.

The Objective: The purpose of this study was to investigate the differences in the characteristics of the 3 rd molar impaction patient in the approval to undergo surgery at Dental and Mouth Polyclinic on General Hospital Doktor Kariadi Semarang, Indonesia.

Method: This is an analytic research with cross sectional approach. The population in this study was molar impaction three patients treated in dental and mouth surgery polyclinic amounting 146 people with sample $30 \%$ out of total population resulting in 44 people. Chi-Square test was used to find out the difference perception characteristics among the respondents.
\end{abstract}

Result: The research shows demographic of respondent are different in age, education, and work between those who agree to do the operation with those who do not. In the psychographic of respondents, there are differences in intelligence, knowledge, attitude, and anxiety.

Conclusion: There are differences in demographic and psychographic characteristics between molar impaction three patients who agree and who do not agree to do surgery. The result brings implication that dentists and dental nurses should always provide therapeutic communication to the patient before treatment is given.

Keywords: Characteristics, Molar Impaction Impact 3, Approval, Surgery

\section{INTRODUCTION}

One of the problems that arise in the act of oral surgery or dental surgery is the problem before surgery that is the feeling of fear or anxiety of patients against surgery. That fear or anxiety about the act of oral surgery can be identified by the stimuli received, for example, fear of needles, fear of tools used for oral surgery and so on. The patient's anxiety affects tooth extraction action is evidenced by the research done Pranoto, et al. (2009) stated that patients with dental and oral diseases requiring exodontia remedial action refused the tooth extraction because they experienced severe anxiety levels.
Registration for an oral surgeon at polyclinic of General Hospital Doktor Kariadi Semarang per month counted averagely 50 people. This trend shows that the high number of dental and oral cases that should be treated with oral surgery, but not all patients want to do surgery. The reluctance might be influenced by psychographic characteristics described in the knowledge, attitude, anxiety, and demographic characteristics described in age, education, and type of work. There are differences in features and psychographics of molar impaction patients three who agree and disagree with surgery. The purpose of the study was to investigate differences in the characteristics of patients with molar impaction three on approval to undergo surgery at Dental and Oral Polyclinics of the 
Demographic and Psychographic Characteristics of Patients with Molar Impaction 3 on the Approval of Surgery in Dental and Oral Polyclinic

General Hospital Doktor Kariadi Semarang, Indonesia.

\section{MATERIALS AND METHODS}

This research was an analytic research with cross sectional approach. The population in this study was molar impaction three patients treated with dental polyclinic and mouth surgery of General Hospital Doctor Kariadi Semarang amounted approximately 146 people. The sample size of $30 \%$ of the total population was taken by using purposive sampling technique. Those samples were encountered at the time of the study, i.e., patients who came to check the teeth with complaints of $3 \mathrm{rd}$ molar teeth. The number of samples as many as 44 people who meet the criteria of the sample: new patients who treated with the oral surgery Dental and Mouth Policlinic General Hospital Doktor Kariadi Semarang and aged 17 years up to 35 years. The sample was divided into two groups namely group I amounted to 22 people who are the respondents who agreed to perform the operation action and group II amounted to 22 people who are the respondents who do not agree to do the surgery.

Univariate analysis was used to describe each independent variable and dependent variable through frequency distribution and percentage.

- Intelligence is the level of intelligence, capture, analysis, synthesis, practical, concrete ability, memory, and numerical ability. Intelligence is categorized into two things, namely: good and less.

- Knowledge is the level of respondents knew about dental and oral health especially about the action of dental surgery. Knowledge is categorized into good and bad.

- Attitude is the view of the patient at the time of action will be done three molar impaction surgeries which are classified as good and bad.

- Anxiety is the feeling of fear/anxiety experienced by the patient before the action of molar impaction three is done categorized as anxious and not concerned.

Bivariate analysis was performed to analyze the difference of demographic and psychographic characteristics of 3rd molar impaction patient with the consent in having surgery at the General Hospital of Doktor Kariadi Semarang.
The bivariate analysis employed Chi square test with $95 \%$ confidence level.

\section{RESULT}

Characteristics of respondents are presented in the following tables.

Table1. Age difference in respondent's approval to undergo surgery

\begin{tabular}{|l|l|l|l|l|l|}
\hline \multirow{1}{*}{ Ages } & \multicolumn{4}{|c|}{ Agreement in surgery } & \multirow{2}{*}{ p-value } \\
\cline { 2 - 5 } & Agree & \multicolumn{2}{|c|}{ Disagree } & \\
\cline { 2 - 5 } & $\begin{array}{l}\text { Freque } \\
\text { ncy (n) }\end{array}$ & $\begin{array}{l}\text { Perce } \\
\text { ntage } \\
(\%)\end{array}$ & $\begin{array}{l}\text { Freque } \\
\text { ncy (n) }\end{array}$ & $\begin{array}{l}\text { Perce } \\
\text { ntage } \\
(\%)\end{array}$ & \\
\cline { 1 - 5 } $\begin{array}{l}\text { Teenage } \\
\text { rs }\end{array}$ & 9 & 40.9 & 0 & 0 & 0.001 \\
\hline Adults & 13 & 59.1 & 22 & 100 & \\
\hline Total & 22 & 100 & 22 & 100 & \\
\hline
\end{tabular}

Table 1 show that all adults (100\%) disagree toward surgery while those who agree are also majority adults $(59.1 \%)$. Since the p-value is below 0.05 , it is concluded that the difference is significant.

Table2. Education difference in respondent's approval to undergo surgery

\begin{tabular}{|l|l|l|l|l|l|}
\hline \multirow{4}{*}{ Ages } & \multicolumn{4}{|c|}{ Agreement in surgery } & p-value \\
\cline { 2 - 5 } & Agree & \multicolumn{2}{|c|}{ Disagree } & \\
\cline { 2 - 5 } & $\begin{array}{l}\text { Freque } \\
\text { ncy }(\mathrm{n})\end{array}$ & $\begin{array}{l}\text { Percenta } \\
\text { ge }(\%)\end{array}$ & $\begin{array}{l}\text { Freque } \\
\text { ncy }(\mathrm{n})\end{array}$ & $\begin{array}{l}\text { Percenta } \\
\text { ge }(\%)\end{array}$ & \\
\hline $\begin{array}{l}\text { Lower } \\
\text { Education }\end{array}$ & 6 & 27.3 & 14 & 63.6 & 0.015 \\
\hline $\begin{array}{l}\text { Higher } \\
\text { Education }\end{array}$ & 16 & 72.7 & 8 & 36.4 & \\
\hline Total & 22 & 100 & 22 & 100 & \\
\hline
\end{tabular}

Table 2 shows that those in higher education $(72.7 \%)$ agree toward surgery while those who disagree majority are in lower education (63.6 $\%)$. Since the p-value is below 0.05 , it is concluded that the difference is significant.

Table3. Job difference in respondent's approval to undergo surgery

\begin{tabular}{|c|c|c|c|c|c|}
\hline \multirow[t]{3}{*}{ Ages } & \multicolumn{4}{|c|}{ Agreement in surgery } & \multirow[t]{3}{*}{ p-value } \\
\hline & \multirow{2}{*}{\begin{tabular}{|l} 
Agree \\
Frequen \\
cy $(\mathrm{n})$
\end{tabular}} & \multicolumn{3}{|c|}{ Disagree } & \\
\hline & & $\begin{array}{l}\text { Percent } \\
\text { age } \\
(\%)\end{array}$ & $\begin{array}{l}\text { tFrequen } \\
\text { cy (n) }\end{array}$ & $\begin{array}{l}\text { Percentage } \\
(\%)\end{array}$ & \\
\hline \begin{tabular}{|l|} 
Public \\
Servant \\
\end{tabular} & 13 & 59.1 & 5 & 22.7 & 0.014 \\
\hline Private & 9 & 40.9 & 17 & 77.3 & \\
\hline TOTAL & & 100 & 22 & 100 & \\
\hline
\end{tabular}

Table 3 shows that those work as a public servant, the maority $(59.1 \%)$ agree toward surgery while those who disagree majority work in the private sector $(77.3 \%)$. Since the p-value is below 0.05 , it is concluded that the difference is significant. 
Demographic and Psychographic Characteristics of Patients with Molar Impaction 3 on the Approval of Surgery in Dental and Oral Polyclinic

Table4. Intelligence difference in respondent's approval to undergo surgery

\begin{tabular}{|l|l|l|l|l|l|}
\hline \multirow{5}{*}{ Intelligence } & \multicolumn{3}{|c|}{ Agreement in surgery } & p-value \\
\cline { 2 - 5 } & Agree & \multicolumn{2}{|l|}{ Disagree } & \\
\cline { 2 - 5 } & $\begin{array}{l}\text { Frequ } \\
\text { ency } \\
(\mathrm{n})\end{array}$ & $\begin{array}{l}\text { Percen } \\
\text { tage } \\
(\%)\end{array}$ & $\begin{array}{l}\text { Frequen } \\
\text { cy (n) }\end{array}$ & $\begin{array}{l}\text { Percen } \\
\text { tage } \\
(\%)\end{array}$ & \\
\hline Good & 11 & 50 & 3 & 13.6 & 0.022 \\
\hline Less & 11 & 50 & 19 & 86.4 & \\
\hline TOTAL & 22 & 100 & 22 & 100 & \\
\hline
\end{tabular}

Table 4 shows those who disagree majority work in less intelligence $(86.4 \%)$. Since the pvalue is below 0.05 , it is concluded that the difference is significant.

Table5. Knowledge difference in respondent's approval to undergo surgery

\begin{tabular}{|l|l|l|l|l|l|}
\hline \multirow{5}{*}{ Knowledge } & \multicolumn{3}{|c|}{ Agreement in surgery } & p-value \\
\cline { 2 - 5 } & Aggee & \multicolumn{2}{l|}{ Disagree } & \\
\cline { 2 - 5 } & $\begin{array}{l}\text { Frequ } \\
\text { ency } \\
(\mathrm{n})\end{array}$ & $\begin{array}{l}\text { Percent } \\
\text { age (\%) }\end{array}$ & $\begin{array}{l}\text { Freque } \\
\text { ncy (n) }\end{array}$ & $\begin{array}{l}\text { Percent } \\
\text { age (\%) }\end{array}$ & \\
\hline Good & 20 & 90.9 & 12 & 54.5 & 0.016 \\
\hline Bad & 2 & 9.1 & 10 & 45.5 & \\
\hline TOTAL & 22 & 100 & 22 & 100 & \\
\hline
\end{tabular}

Table 5 shows those who agree majority has good knowledge $(90.9 \%)$. Since the p-value is below 0.05 , it is concluded that the difference is significant.

Table6. Attitude difference in respondent's approval to undergo surgery

\begin{tabular}{|c|c|c|c|c|c|}
\hline \multirow{3}{*}{ Attitude } & \multicolumn{4}{|c|}{ Agreement in surgery } & \multirow{3}{*}{ p-value } \\
\hline & \multicolumn{2}{|c|}{ Agree } & \multicolumn{2}{|c|}{ Disagree } & \\
\hline & $\begin{array}{l}\text { Freque } \\
\text { ncy (n) }\end{array}$ & $\begin{array}{l}\text { Percent } \\
\text { age }(\%)\end{array}$ & $\begin{array}{c}\text { Frequen } \\
\text { cy (n) }\end{array}$ & $\begin{array}{l}\text { Percent } \\
\text { age }(\%)\end{array}$ & \\
\hline $\mathrm{Bad}$ & 1 & 4.5 & 19 & 86.4 & \multirow{2}{*}{0.0001} \\
\hline Good & 21 & 95.5 & 3 & 13.6 & \\
\hline TOTAL & 22 & 100 & 22 & 100 & \\
\hline
\end{tabular}

Table 6 shows those who agree majority has good attitude $(95.5 \%)$. Since the p-value is below 0.05 , it is concluded that the difference is significant.

Table7. Anxiety difference in respondent's approval to undergo surgery

\begin{tabular}{|l|l|l|l|l|l|}
\hline \multirow{3}{*}{ Anxiety } & \multicolumn{3}{|c|}{ Agreement in surgery } & \multirow{2}{*}{ p-value } \\
\cline { 2 - 5 } & Agree & \multicolumn{2}{|l|}{ Disagree } & \\
\cline { 2 - 5 } & $\begin{array}{l}\text { Frequen } \\
\text { cy }(\mathrm{n})\end{array}$ & $\begin{array}{l}\text { Percent } \\
\text { age }(\%)\end{array}$ & $\begin{array}{l}\text { Frequen } \\
\text { cy }(\mathrm{n})\end{array}$ & $\begin{array}{l}\text { Percent } \\
\text { age }(\%)\end{array}$ & \\
\hline Relaxed & 17 & 77.3 & 0 & 0 & 0.0001 \\
\hline Worried & 5 & 22.7 & 22 & 100 & \\
\hline TOTAL & 22 & 100 & 22 & 100 & \\
\hline
\end{tabular}

Table 6 shows those who agree on majority in a relaxed condition $(77.3 \%)$, and all respondents who are worried do not agree with the surgery. Since the p-value is below 0.05 , it is concluded that the difference is significant.

\section{DISCUSSION}

Table 1 shows that there is a significant age difference in the respondents in the approval of surgery, as evidenced by $p$-value $=0.001$. This is because when someone is getting older, he/she becomes more responsiveness and experience. As the experience increases, more thought is being considered to decide.

Experience can be accepted by the community through living processes, various media, both print and electronic media. As a result, people who experience unpleasant events and are more often exposed to the mass media or listen to stories from others will gain more information and expertise than individuals who are not vulnerable to the mass media, so it will be easy in determining attitudes or making decisions (Sri Eniyati, 2011). This finding is in line with Ruwanti (2006) that the quality of individual thinking is influenced by age, education level, attitude, and personality.

Table 2 shows that there is a significant difference in the upbringing among respondents in the approval of surgery as evidenced by $p$ value $=0.015$. This is because the highly educated people will be more rational and mature in analyzing an object. A person's level of education will affect responding to something that comes from outside. A highly educated person will provide a more rational response to the information coming and will think the extent to which the benefits may be derived from the idea (Esty Rokhyani, 2009).The higher the level of education a person, the better the solution to the problem and the decision to be taken.

Table 3 shows that there are significant differences in the work of respondents in the approval of surgery as evidenced by $\mathrm{p}$ - value $=$ 0.014 . The difference is due to the work which is closely related to income. People assume that health is the most important thing in life, but a person still has to make a priority in fulfilling the needs of his life. This is in line with Latipun (2001) that the economic status of a family affects the fulfillment of primary and secondary needs. This will also affect the family's health needs. Families with low economic status will surely override the necessity of health satisfaction, as it is not including the primary needs.

Someone will feel optimal in doing his job when they are in good health. According to Munir, income levels will affect a person's role, 
meaning that one's income will be used to meet a person's minimum physical needs. With the minimum physical needs of a person fulfilled, the role of people in improving health status can be done well (Dhini Rama Dhania, 2010) while another opinion says that socioeconomic status will affect a person's decision making (Helper Sahat P. Manalu, 2010).

Table 4 shows that there is a significant difference in intelligence to the respondents in the approval of surgery evidenced by the $\mathrm{p}$ value $=0.022$. The condition is because intelligence is a mental ability that involves the process of reasoning in problem-solving and decision making. Therefore information significantly affects a person in deciding (Moch. Luqman Zuhdi, 2014). Rapid reactions or adjustments both physically and mentally to new experiences and situations make the experience and knowledge available to be ready for use when finding in new factors or conditions (Mira Gusniwati, 2015). Individual intelligence affects decision making has been proven research conducted by Kawakib (2008) which states that there is a significant relationship between knowledge with a person in making decisions.

Table 5 shows that there is a significant difference of knowledge among respondents in the approval of surgery as evidenced by p-value $=0.016$. Knowledge is the result of knowing, and this occurs after people have sensed a particular object (Rahman, et.al 2011). This is done by observing all facts relating to the object of observation (Machin, 2014) and the conclusions are taken into new knowledge (Notoatmodjo, 2012).

Table 6 shows that there are significant differences in attitude among respondents in the approval of surgery as evidenced by p-value < 0.0001 . This is because decision making is a habit-based behavior. The habit starts from attitude and attitude influenced by paradigm, while model influenced by knowledge (Nurhayati. 2010). A person's decision-making image will be visible from the person's attitude. A person behaves included in decision-making, is based on assumptions: 1) people do things in a reasonable way; 2) people consider all available information; 3) explicitly or implicitly humans considering the implications of their actions. These three are influenced by attitudes (Kamisah Osman et.al, 2007).
Table 7 shows that there are significant anxiety differences in the respondents in the approval of surgery as evidenced by the value of $p<0.0001$. The existence of differences in patients who agree to do surgery with the disagree caused by the fear of excessive so that anxiety arises in the individual. People with high anxiety before surgery will affect the process and results of operation, for which one tends to refuse surgery. Anxiety manifestations are identified in four aspects of response: 1) physical response: such as difficulty sleeping, chest pounding, sweaty body though not hot, hot or cold body, headache, muscle tension, or stiffness, abdominal pain or constipation, Puffing or shortness of breath; 2) responsive feelings, such as feeling themselves in a fantasy, derealization, feeling helpless, and fear of something that will happen; 3) response of the mind, like thinking the worst thing will happen and often think of danger; 4) response behavior, such as away from a scary situation, easily startled, hyperventilation, and reduce the routine (Wening Dwijayanti et.al, 2014).

\section{CONCLUSION}

In the demographic of respondents, there was a significant age difference, education, work toward the agreement on surgery. Similarly, in psychographic, there was a significant difference in intelligence, knowledge, attitude, and anxiety. These differences confirm significant differences in characteristics of patients with molar three impaction who agree and who do not agree to do surgery at Dental and Mouth Polyclinic General Hospital Doktor Kariadi Semarang.

To avoid people's fears and anxieties about the treatment/operation of dental and oral diseases, health care providers are expected to provide health care to the public about oral health through extension activities. The activities may include the dentist, and dental nurse should always provide therapeutic communication to the patient before treatment is given to the patient, especially before surgery.

\section{REFERENCES}

[1] Abdul Rochim, 2010, Tingkat Kesulitan Operasi Impaksi Molar III Bawah Antara Posisi Vertikal Dibandingkan Posisi Mesioanguler. Stomagtogbatig Jurnal Kedokteran Gigi. Vol 7, No 2 (2010). ISSN: 2442-4935

[2] Esty Rokhyani, 2009. Efektifitas Konseling Rasional Emotif Dengan Teknik Relaksasiuntuk Membantu Siswa Mengatasi 
Kecemasan Menghadapi Ujian. E-Jurnal UNESA, Psikologi Pendidikan dan Bimbingan Vol 10, No 2,(2009ISSN : 1411- 3376.

[3] Dhini Rama Dhania, 2010. Pengaruh Stres Kerja, Beban Kerja Terhadap Kepuasan Kerja (Studi Pada Medical Representatif Di Kota Kudus). Jurnal Psikologi Universitas Muria Kudus Universitas Muria Kudus Volume I, No 1, Desember 2010. ISSN: 2442-4918

[4] Helper Sahat P. Manalu, 2010. Aktor-Faktor Yang Mempengaruhi Kejadian TB Paru Dan Upaya Penanggulangannya, Jurnal Ekologi Kesehatan Vol 9, No 4 Des (2010).p-ISSN: 1412-4025, e-ISSN: 2354-875.

[5] Kamisah Osman, Zanaton Haji Iksan, Lilia Halim, 2007, Sikap terhadap sains dan sikap saintifik di kalangan pelajar sains. Jurnal Pendidikan Malaysia, 32 . pp. 39-60. ISSN 0126-6020 / 2180-0782

[6] Kawakib (2008, Hubungan Anatara Inteklegensi, Karir Self Efficacy, Status Social Ekonomi Orang Tua Dan Pengambilan Karir Siswa SMA Negeri Pamekasan . http://karya ilmiah.um.ic.id

[7] Latipun, 2001, Psikologi Konseling, UMM Press, Malang

[8] Machin, A. Implementasi Pendekatan Saintifik, Penanaman Karakter Dan Konservasi Pada Pembelajaran Materi Pertumbuhan. Jurnal Pendidikan IPA Indonesia. 3 (1) (2014)

28-35.

http://journal.unnes.ac.id/nju/index.php/jpii

[9] Mira Gusniwati, 2015. Pengaruh Kecerdasan Emosional Dan Minat Belajar Terhadap Penguasaan Konsep Atematika Siswa Sman Di Kecamatan Kebon Jeruk. Jurnal Formatif 5(1): 26-41, 2015 ISSN: 2088-351X

[10] Moch. Luqman Zuhdi. 2014. Kontribusi Intelegensi Terhadap Pembelajaran Keterampilan Gerak Dasar Shooting Bolabasket Pada Siswa Kelas X Sman 4 Kediri. Jurnal Pendidikan Olahraga dan Kesehatan Volume 02 Nomor 02 Tahun 2014, 444 - 447444. ISSN : 2338-798X.
[11] Notoatmodjo, 2012, Pendidikan Dan Perilaku Kesehatan, Rineka Cipta, Jakarta

[12] Nurhayati. 2010. Pengaruh Sikap Dan Kebiasaan Tehadap Hasil Belajar Matematika (Survey pada siswa kelas VIII SMPN di Kecamatan Kramat Jati Jakarta Timur Tahun ajaran 2009/2010). Jurnal Formatif 1(3): 247254 ISSN:2088-351. Hal. 247-254.

[13] Padmi Dhyah Yuliant, 2011. Pengaruh Pelatihan Asertivitas Dalam Mengurangi Kecemasan Pada Korban Tindak Kekerasan Dalam Rumah Tangga. Jurnal Penelitian Psikologi Pendidikan dan Bimbingan (JP3B).Vol 1, No 1 (2011) ISSN: 20865503.

[14] Pranoto dan Budi, 2009., Hubungan Kecemasan Pasien Terhadap Tindakan Pencabutan Gigi Di Pliliklinik Gigi RSUP Dr Kariadi Semarang, Skripsi, Semarang

[15] Rahman, F., Khalil, J. K., Jumani, N. J., Ajmal, M., Malik, S., \& Sharif, M. (2011). Impact of Discussion Method on Students

[16] Ruwanti (2006), Pengaruh Kecerdasan Emosiaonala Terhadap Pengambilan Keputusan Pada Sentra Industry Kecil Menengah (IKM) Sepatu Cibaduyut Di Kecamatan Bjongloa Kidul, http://digilib.upi.edu/index.php/record/view/, 22 - 7-2009.

[17] Sri Eniyati, Perancangan Sistem Pendukung Pengambilan Keputusan untuk Penerimaan Beasiswa dengan Metode SAW (Simple Additive Weighting). Jurnal Teknologi Informasi DINAMIK Volume 16, No.2,Juli 2011 : 171176 ISSN : 08549524

[18] Triana Rostiana, Ni Made Taganing Kurniati, 2009. Kecemasan Pada Wanita Yang Menghadapi Menopause. Jurnal Psikologi Volume 3, No.1, Desember $2009 . \quad$ Hal. 7686

[19] Wening Dwijayanti, Sri Sumarni, Ida Ariyanti,2014. Efek Aromaterapi Lavender Inhalasi terhadap Intensitas Nyeri Pasca Sectio Caesaria. Jurnal Medica Hospitalia, Med Hosp 2014;vol2 (2) : 120-125.

Citation: Nasri, Sri Subekti, Bedjo Santoso, Ratna Wilis . Demographic and Psychographic Characteristics of Patients with Molar Impaction 3 on the Approval of Surgery in Dental and Oral Polyclinic. ARC Journal of Surgery.2017; 3(1):14-18. doi:dx.doi.org/10.20431/2455-572X.0301005.

Copyright: (C) 2017 Authors. This is an open-access article distributed under the terms of the Creative Commons Attribution License, which permits unrestricted use, distribution, and reproduction in any medium, provided the original author and source are credited. 